\title{
APPLYING DEA MODEL TO MEASURE THE EFFICIENCY OF HOSPITALITY SECTOR: THE CASE OF VIETNAM
}

\section{NHU-TY NGUYEN*, LINH-XUAN THI NGUYEN}

School of Business, International University - Vietnam National University HCMC; Quarter 6, Linh
Trung ward, Thu Duc district, HCMC, Vietnam; E-Mail: nhutynguyen@hcmiu.edu.vn (N.-T., Nguyen)

*Corresponding author: nhutynguyen@hcmiu.edu.vn

\begin{abstract}
Tourism industry is one of the world's largest industries with a global economic contribution of over 7.6 trillion dollars in 2016 which provides an equal or even surpasses the business volume of oil exports, and food and beverage.As the current climate of the globe, Vietnam's tourism in general, hospitality in particular has attracted investment from not only domestic enterprises but many international hospitality corporations which create a fierce competitive than ever.Identifying inefficient activities and providing improvement in whole process is crucial. The present research aims to study and evaluate the performance of Vietnam hospitality industry through 20 chosen companies that qualify criteria of Data Envelopment Analysis (DEA) model and Malmquist productivity index. It would be a useful tool in benchmarking the efficient firms and inefficient ones operating in the industry and help the former to improve their efficiency. The researcher uses 5 input variables (Cost of good sales; sales expense; operation expense; fixed assets and owner equity) and 2 output variables (Revenues and Profit after tax).DMU1 and DMU8 face with huge fluctuation in efficiency which acquires the management board to review and improve their operation process to ensure the sustainable development of the firm in current competitive market.
\end{abstract}

Received 2019-05-06; accepted 2019-07-03; published 2019-11-01.

2010 Mathematics Subject Classification. 91B02.

Key words and phrases. Hospitality; evaluation; forecasting; DEA; GM(1,1).

(C)2019 Authors retain the copyrights of their papers, and all open access articles are distributed under the terms of the Creative Commons Attribution License. 


\section{Introduction}

Nowadays, tourism industry is one of the world's largest industries with a global economic contribution of over 7.6 trillion dollars in 2016 which provides an equal or even surpass the business volume of oil exports, and food and beverage. Tourism has significant grown and various diversification to be one of the fastest growing industry. The development of national economy and encircles a growing number of new destinations encouraged the development of modern tourism. As the current climate of the globe, Vietnam's tourism in general, hospitality in particular has attracted investment from not only domestic enterprises but many international hospitality corporations which create a fierce competitive than ever.

Hospitality's benefit will go toward the development of tourist and the competition can be expected. Global hospitalities like Six Sense, Sheraton, Nikko, ect. has joined to the competition. Hotel managers agree that enhancing their performance can be their advantages and those advantages can be identified with the competitive benchmarking ([1]). As the nature of hotel service is simultaneous and perishable, how to manage the customer demands and service capacity will affect in the profitability of company ([2]). How to efficiently operate in comparation with industrial benchmark and rivals is crucial in this industry.

Identifying inefficient activities and providing improvement in whole process is crucial. The present research aims to study and evaluate the performance of Vietnam hospitality industry through 20 chosen companies that qualify criteria of Data Envelopment Analysis (DEA) model and Malquist productivity index. It would be a useful tool in benchmarking the efficient firms and inefficient ones operating in the industry and help the former to improve their efficiency

The objectives of the research are summarized as following:

b. To evaluate the efficiency of 20 listed firms in Vietnam hospitality industry using the data for the past 5 years from 2013 to 2017

c. To forecast the performance of those 20 DMUs in the next 5 years from 2018 to 2022 and then use the forecasted data an input to evaluate their performances

d. To compare the efficiency of the past and the future between the set of data 20132017 and the set of data 2018-2022 in order to evaluate the past-to-future performance. 


\section{Literature Review}

The Grey System Theory, introduced by professor Deng Julong in 1988 whichis well known as beneficial tool to take uncertain system with "small sample and poor information" as the research object. Moreover, it is a useful method to forecast and has been applied successfully in many fields and present satisfaction results. Recently, the application of the systems has be successfully employed in calculating of input and output values of organizations, agriculture, meteorological, forestry and disaster predictions. The method is not complicated and be used easily. The small set of data can be used rather than a large number of data. Therefore, it is practically to apply the method in the paper.

Data envelopment analysis (DEA) is popular in new researchers which is suggested firstly in 1978 byCharnes, Cooper and Rodes. DEA is a nonparametric method in which the researcher is allowed to use multiple inputs and outputs. The inputs and outputs are combined, the relative efficiency for a whole organization or parts of an organization (or called decisionmaking units [DMUs]) is calculated. In a sample of DMUs, the best performing ones is identified. An efficiency frontier is, the DMUs on the frontier are efficient (best practice) and the ones that are below efficiency frontier are inefficient. The efficiency index will have values from 0 to 1 (or 0 to $100 \%$ ). The result 1 implied the efficient unit and vice versa the result less than 1 represents the inefficient. The DMUs in DEA in the sample have similar activities so that a similar group of inputs and outputs can be identified. Moreover, the DMUs have to operate in a similar environment ([3]). Different from the traditional accounting method, DEA model has the benefits that it is proper to compare the relative performance between multiple performance measures ([4]). There are two approaches in DEA: (1) The input-oriented approach and (2) The out-put oriented approach. The input-oriented approach argues minimization of input for the given outputs. Meanwhile, the output-oriented approach is the maximization of outputs for the given inputs.

Table 2.1 indicates several previous studies that applied DEA model in evaluating the performance and efficiency of companies in hospitality industry in different countries and some similar industries as well. 
Table 2. 1 - Table of input and output

\begin{tabular}{|c|c|c|}
\hline Author & INPUT & OUTPUT \\
\hline $\begin{array}{l}\text { Johns, Howcroft, and } \\
\text { Drake (1997) [5] }\end{array}$ & $\begin{array}{l}\text { Available room nights, labourtimes, food and } \\
\text { beverage costs and utilities cost }\end{array}$ & $\begin{array}{l}\text { Number of room night sold, } \\
\text { reserved cost, food and } \\
\text { beverage revenue }\end{array}$ \\
\hline $\begin{array}{l}\text { Hwang and Chang (2003) } \\
\text { [6] }\end{array}$ & $\begin{array}{l}\text { Number of full-time employees, number of } \\
\text { rooms, food and beverage department areas, } \\
\text { operating expenses }\end{array}$ & $\begin{array}{l}\text { Revenue of each divisions: } \\
\text { room, food and beverage; } \\
\text { and other revenue }\end{array}$ \\
\hline $\begin{array}{l}\text { Chiang, Tsai, and Wang } \\
\text { (2004) [7] }\end{array}$ & $\begin{array}{l}\text { Number of hotel rooms, food and beverage } \\
\text { department areas, employees, total cost }\end{array}$ & $\begin{array}{l}\text { Yielding index, food and } \\
\text { beverage revenue, other } \\
\text { revenue }\end{array}$ \\
\hline Barros (2005) [8] & $\begin{array}{l}\text { Number of full-time employees, cost of } \\
\text { labour, rooms, hotel areas, property's book } \\
\text { value, operation expenses, external expense }\end{array}$ & $\begin{array}{l}\text { Sales revenue, Number of } \\
\text { guests, and number of night } \\
\text { stay }\end{array}$ \\
\hline $\begin{array}{l}\text { Barros and Santos (2006) } \\
\text { [9] }\end{array}$ & $\begin{array}{l}\text { Number of full-time employees, cost of } \\
\text { labour, capital }\end{array}$ & $\begin{array}{l}\text { Sales revenue, added value, } \\
\text { earnings }\end{array}$ \\
\hline $\begin{array}{l}\text { Önüt and Soner (2006) } \\
\text { [10] }\end{array}$ & $\begin{array}{l}\text { Number of full-time employees, consumption } \\
\text { of electricity, water and liquefied }\end{array}$ & $\begin{array}{l}\text { Occupancy rate, sales } \\
\text { revenue, number of guests }\end{array}$ \\
\hline Chen (2007) [11] & cost of labour, cost of F\&B, cost of materials & Total revenue \\
\hline Davutyan (2007) [12] & $\begin{array}{l}\text { Number of available beds, Number of full- } \\
\text { time employees, operating cost }\end{array}$ & $\begin{array}{l}\text { Beds sold to return } \\
\text { customers divided by } \\
\text { number of available beds, } \\
\text { beds sold }\end{array}$ \\
\hline Min et al. (2008) [13] & $\begin{array}{l}\text { Sales expense, total labour cost, operation } \\
\text { expenses and non-operating expenses }\end{array}$ & $\begin{array}{l}\text { Revenue of each divisions: } \\
\text { room, food and beverage; } \\
\text { and other revenue }\end{array}$ \\
\hline Barros et al. (2009) [14] & $\begin{array}{l}\text { Number of full-time employees, physical } \\
\text { capital }\end{array}$ & Sales revenue, added value \\
\hline $\begin{array}{l}\text { Neves and Lourenco } \\
\text { (2009) [15] }\end{array}$ & $\begin{array}{l}\text { Cost of goods and services, Current assets, net } \\
\text { fixed assets, andowner equity, }\end{array}$ & $\begin{array}{l}\text { Revenues and earnings } \\
\text { (EBITDA) }\end{array}$ \\
\hline Perrigot et al. (2009) [16] & $\begin{array}{l}\text { Hotel establish ages, number of labour, } \\
\text { Number of rooms. Number of hotel openings } \\
\text { during the year, franchising contract: royalties } \\
\text { in percentage, chain ranking }\end{array}$ & $\begin{array}{l}\text { Sales revenue, room } \\
\text { revenues, other revenues } \\
\text { and occupancy rate }\end{array}$ \\
\hline
\end{tabular}




\begin{tabular}{|c|c|c|}
\hline Yu and Lee (2009) [17] & $\begin{array}{l}\text { Full-time employees in each department: the } \\
\text { room service department, the F\&B } \\
\text { department, number of hotel rooms, floor area } \\
\text { in the F\&B service department; cost for each } \\
\text { service sector, shared input }\end{array}$ & $\begin{array}{l}\text { Revenue of each divisions: } \\
\text { room, food and beverage; } \\
\text { and other revenue }\end{array}$ \\
\hline $\begin{array}{l}\text { Chen, Hu, and Liao } \\
\text { (2010) [18] }\end{array}$ & $\begin{array}{l}\text { Number of hotel rooms; Number of } \\
\text { employees; floor area in the F\&B service } \\
\text { department }\end{array}$ & $\begin{array}{l}\text { Revenue of each divisions: } \\
\text { room, food and beverage; } \\
\text { and other revenue }\end{array}$ \\
\hline Hsieh and Lin (2010) [19] & $\begin{array}{l}\text { Room expenses, number of employees of the } \\
\text { room department, food and beverage cost, } \\
\text { employees of food and beverage department; } \\
\text { area of rooms, catering floors }\end{array}$ & $\begin{array}{l}\text { Revenue of room service, } \\
\text { food and beverage service }\end{array}$ \\
\hline Hsieh et al. (2010) [20] & $\begin{array}{l}\text { Number of hotel rooms; Number of } \\
\text { employees, facilities expenses, operation } \\
\text { expenses }\end{array}$ & $\begin{array}{l}\text { Occupancy rate, sales } \\
\text { revenue }\end{array}$ \\
\hline $\begin{array}{l}\text { Assaf and Magnini (2011) } \\
\text { [21] }\end{array}$ & $\begin{array}{l}\text { Number of hotel rooms; Number of } \\
\text { employees, operational costs }\end{array}$ & $\begin{array}{l}\text { Occupancy rate, sales } \\
\text { revenue }\end{array}$ \\
\hline Avkiran (2011) [22] & $\begin{array}{l}\text { Number of Full-time staff, permanent part- } \\
\text { time staff, Number of room }\end{array}$ & $\begin{array}{l}\text { Sales Revenue and a double } \\
\text { room cost }\end{array}$ \\
\hline Chen (2011) [23] & $\begin{array}{l}\text { Number of employees, area of floors, guest } \\
\text { rooms, operation expenses, and depreciation } \\
\text { expenses }\end{array}$ & $\begin{array}{l}\text { Occupancy rate, number of } \\
\text { guests and guest } \\
\text { satisfaction index, Room } \\
\text { revenue, other revenue }\end{array}$ \\
\hline $\begin{array}{l}\text { Yen and Othman (2011) } \\
\text { [24] }\end{array}$ & $\begin{array}{l}\text { Number of full-time employees, cost of } \\
\text { labour, rooms, hotel areas, property's book } \\
\text { value, operation expenses, external expense }\end{array}$ & $\begin{array}{l}\text { No nights occupied, } \\
\text { number of guests; } \\
\text { occupancy rate, revenue of } \\
\text { room service, food and } \\
\text { beverage service }\end{array}$ \\
\hline $\begin{array}{l}\text { Honma and } \mathrm{Hu}(2012) \\
{[25]}\end{array}$ & $\begin{array}{l}\text { Number employees, number of temporary } \\
\text { staff, number of seats in restaurants and bars, } \\
\text { number of rooms }\end{array}$ & Sales revenue \\
\hline $\begin{array}{l}\text { Manasakis et al. (2013) } \\
\text { [26] }\end{array}$ & $\begin{array}{l}\text { No. of employees, number employees, } \\
\text { operation expenses }\end{array}$ & $\begin{array}{l}\text { Sales revenues and total } \\
\text { number of spent nights }\end{array}$ \\
\hline $\begin{array}{l}\text { Katarina Poldrugovac, } \\
\text { MetkaTekavcic\& Sandra } \\
\text { Jankovic (2016) [27] }\end{array}$ & $\begin{array}{l}\text { Expenses of each division: Room, Energy, } \\
\text { F\&B, labor and other }\end{array}$ & $\begin{array}{l}\text { Sales revenue and } \\
\text { occupancy rate }\end{array}$ \\
\hline
\end{tabular}




\section{Methodologies}

\subsection{Collecting DMUs}

The research was only conducted 20 companies whose financial reports are audited by reliable institutions and collected from Vietnam Stock Exchanges Market or company's official website from 2013 to 2017 and denoted from DMU1 to DMU20 as the order in the table 3.1. in addition, the financial result of Vietnam hospitality companies from 2013 to 2017 are also generated in the bellow table:

4. Table 3. 2 - Decision making unit

\begin{tabular}{|c|c|c|c|}
\hline Number & Code & Company name & Denote \\
\hline 1 & DMU1 & $\begin{array}{l}\text { BEN THANH TOURIST AND SERVICE } \\
\text { JSC }\end{array}$ & BTV \\
\hline 2 & DMU2 & DONG A HOTEL CORP JSC & DAH \\
\hline 3 & DMU3 & DIC TOURIST AND TRADING JSC & DCD \\
\hline 4 & DMU4 & LANG SON EXIM TOURIST JSC & DXL \\
\hline 5 & DMU5 & $\begin{array}{l}\text { COMMERCIAL AND SERVICE JOIN } \\
\text { STOCK JSC INVESTMENT POWER }\end{array}$ & EIN \\
\hline 6 & DMU6 & HOI AN TOURIST SERVICE CO & HOT \\
\hline 7 & DMU7 & POST HOTEL JSC & $\mathrm{NPH}$ \\
\hline 8 & DMU8 & $\begin{array}{l}\text { NINH VAN BAY TRAVEL REAL } \\
\text { ESTALE JSC }\end{array}$ & NVT \\
\hline 9 & DMU9 & OCEAN HOTEL \& SERVICE JSC & $\mathrm{OCH}$ \\
\hline 10 & DMU10 & $\begin{array}{l}\text { PETROLEUM PHUONGDONG } \\
\text { TOURISM JSC }\end{array}$ & PDC \\
\hline 11 & DMU11 & SAI GON HOTEL JSC & SGH \\
\hline 12 & DMU12 & THUY TA JSC & TTJ \\
\hline 13 & DMU13 & VUNG TAU INTOURCO RESORT & VIR \\
\hline 14 & DMU14 & $\begin{array}{l}\text { THANH CONG TOURIST \& SERVICE } \\
\text { JSC }\end{array}$ & VNG \\
\hline 15 & DMU15 & $\begin{array}{l}\text { CORPORATION TOURIST OF BARIA } \\
\text { VUNG TAU }\end{array}$ & VTG \\
\hline 16 & DMU16 & Dak Lak Tourist Jsc. & DLD \\
\hline 17 & DMU17 & MY TRA TOURIST \& SERVICE CO & MTC \\
\hline 18 & DMU18 & $\begin{array}{l}\text { THE NATIONAL OIL SERVICE JSC OF } \\
\text { VIETNAM }\end{array}$ & OSCVN \\
\hline 19 & DMU19 & DONG NAI TOURIST CO & DNT \\
\hline 20 & DMU20 & KIM LIEN TOURIST CO & KimLien \\
\hline
\end{tabular}




\subsection{DEA - Malmquist Productivity Index}

One of the standard approaches for measuring productivity that applied in many researches overtime is the Malmquist productivity index, especially when nonparametric specifications are applied to micro data. Malmquist productivity index was first proposed by Caves, Christensen and Diewert (1982) and then further modified later by Färe, Grosskopf, Lidgren and Roos in 1995. Malmquist productivity index (MPI) is a tool for measurement of productivity changes of a DMU over periods of time. It is defined as the product of "catch-up" and "frontier-shift" terms. The catch-up term is the degree of efforts that the DMU attained for improving its efficiency, while the frontier-shift term reflects the change in the efficient frontiers surrounding the DMU between the two time periods 1 and 2.

$\mathrm{DMU}_{0}$ at periods 1 and 2 is denoted by $\left(x_{0}^{1}, y_{0}^{1}\right)$ and $\left(x_{0}^{2}, y_{0}^{2}\right)$. The efficiency score of $\operatorname{DMU}\left(x_{0}, y_{o}\right)^{t_{1}}$ is measured by the technological frontier $t_{2}$ :

$$
d^{t_{2}}\left(\left(x_{0}, y_{0}\right)^{t_{1}}\right)\left(t_{1}=1,2 \text { and } t_{2}=1,2\right)
$$

$\mathrm{C}$ stands for the efficiency change (Catch- up effect) and is determined by the following formula:

$$
C=\frac{d^{2}\left(\left(x_{0}, y_{o}\right)^{2}\right)}{d^{1}\left(\left(x_{0}, y_{o}\right)^{1}\right)}
$$

The technological change (frontier-shift effect) denoted by $\mathrm{F}$ has the formula:

$$
F=\left[\frac{d^{1}\left(\left(x_{0}, y_{o}\right)^{1}\right)}{d^{2}\left(\left(x_{0}, y_{o}\right)^{1}\right)} \cdot \frac{d^{1}\left(\left(x_{0}, y_{o}\right)^{2}\right)}{d^{2}\left(\left(x_{0}, y_{o}\right)^{2}\right)}\right]^{1 / 2}
$$

Malmquist Productivity Index (MPI) is the product of $\mathrm{C}$ and F, that is, MPI $=($ catch-up) $x$ (frontier-shift) or

$$
M P I=\left[\frac{d^{1}\left(\left(x_{0}, y_{o}\right)^{2}\right)}{d^{1}\left(\left(x_{0}, y_{o}\right)^{1}\right)} \cdot \frac{d^{2}\left(\left(x_{0}, y_{o}\right)^{2}\right)}{d^{2}\left(\left(x_{0}, y_{o}\right)^{1}\right)}\right]^{1 / 2}
$$

If the Malmquist productivity index (MPI) is greater than 1 (MPI>1), it indicates progress in relative efficiency from period 1 to period 2. Productivity remains unchanged if MPI equal to $1(\mathrm{MPI}=1)$ and it demonstrate a regress when MPI is less than $1(\mathrm{MPI}<1)$.

\subsection{Establishing Inputs and Outputs}

Together with the financial report of hotel in Vietnam, there are five inputs chosen are cost of good sales, sales expenses, operation expenses (including electricity and labor cost), fixed assets and equity. The reasons for this range choosing as bellow:

- Cost of good sales is direct cost that contribute to goods and service of hospitality firm. 
- Fixed asset is a long-term tangible piece of property that a firm owns and uses in its operations to generate income. A fixed asset is bought for production or supply of goods or services, for rental to third party or for use in the organization. It has a physical form and is reported on the balance sheet as property, plant and equipment (PP\&E). In this research which related to hospitality, fixed asset is considered to be important due to the information it provides.

- Sales expenses are used for selling activities like incentive, marketing expense. in a hotel, marketing department is indirect factor to raise the sales revenue.

- Operation expenses includes energy expenses, labor cost which is direct factor which create service to provide for customer. In hotel industry, labor or quality of human resource plays a significant role to generate profit.

- Equity or owner's equity presents the owner's fund for business in various operation. Two chosen outputs factors are considered as sales and profit after tax (PAT).

- Sales are the transactions between parties where the buyers receive goods (tangible or intangible), services and/or assets in exchange for money. It can also refer to an agreement between the buyer and seller of the selected good or service.

- Profit after tax is defined as the net amount earned by a business after all taxation related expenses have been deducted. The profit after tax is often assessment of what a business is really earning and hence can use in its operations than its total revenues.

In the previous research, occupancy rate is a non-financial output of equation but it is not objectively provided by Vietnamese hotel company, so we cannot put it in the output variables.

\section{Empirical Result and Analysia}

\subsection{Empirical Result}

A forecast inputs/ outputs of next 5 years from 2019 to 2022 will be generated by GM $(1,1)$ Model. A sample is presented to illustrate the procedure of GM $(1,1)$ forecasting applied in the research. The researcher takes factor of sales revenue of Ben Thanh Tourist and Service JSC. (BTV) in period of time from 2018 to 2022 to demonstrate the calculation process and other variables are calculated in the same way.

The researcher use the $\mathrm{GM}(1,1)$ model for trying to forecast the variance of primitive series as follows. 
First, the primitive series is created:

$$
X^{(0)}=(455,117 ; 601,329 ; 597,653 ; 672,090 ; 814,010)
$$

Secondly, perform the accumulated generating operation (AGO):

$$
\begin{aligned}
& \quad X^{(1)}=(455,117 ; 1,056,446 ; 1,654,099 ; 2,326,189 ; 3,140,199) \\
& x^{(1)}(1)=x^{(0)}(1)=455,117 \\
& x^{(1)}(2)=x^{(0)}(1)+x^{(0)}(2)=1,056,446 \\
& x^{(1)}(3)=x^{(0)}(1)+x^{(0)}(2)+x^{(0)}(3)=1,654,099 \\
& x^{(1)}(4)=x^{(0)}(1)+x^{(0)}(2)+x^{(0)}(3)+x^{(0)}(4)=2,326,189 \\
& x^{(1)}(5)=x^{(0)}(1)+x^{(0)}(2)+x^{(0)}(3)+x^{(0)}(4)+x^{(0)}(5)=3,140,199
\end{aligned}
$$

Third, create the different equations of $\operatorname{GM}(1,1)$

To find $X^{(1)}$ series, and the following mean obtained by the mean equation is

$$
\begin{aligned}
& z^{(1)}(2)=\frac{1}{2}(455,117+1,056,446)=755,781.5 \\
& z^{(1)}(3)=\frac{1}{2}(1,056,446+1,654,099)=1,355,272.5 \\
& z^{(1)}(4)=\frac{1}{2}(1,654,099+2,326,189)=1,990,144 \\
& z^{(1)}(5)=\frac{1}{2}(2,326,189+3,140,199)=2,733,194
\end{aligned}
$$

Fourth, solve the equations.

To find $a$ and $b$, the primitive series values are substituted into Grey differential equation to obtain

$$
\begin{aligned}
& 601,329+a \times 755,781.5=b \\
& 597,653+a \times 1,355,272.5=b \\
& 672,090+a \times 1,990,144=b \\
& 814,010+a \times 2,733,194=b
\end{aligned}
$$

Then, convert the linear equations into the form of a matrix

Let

$$
B=\left[\begin{array}{cc}
-755,781.5 & 1 \\
-1,355,272.5 & 1 \\
-1,990,144 & 1 \\
-2,733,194 & 1
\end{array}\right], \hat{\theta}=\left[\begin{array}{l}
a \\
b
\end{array}\right], y_{N}=\left[\begin{array}{l}
601,329 \\
597,653 \\
672,090 \\
814,010
\end{array}\right] \text {. }
$$

And then use the least square method to find $a$ and $b$ :

$$
\left[\begin{array}{l}
a \\
b
\end{array}\right]=\hat{\theta}=\left(B^{T} y_{N}\right)=\left[\begin{array}{c}
-0.110619605 \\
482,266.0641
\end{array}\right] \text {. }
$$


Use the two coefficients $a$ and $b$ to generate the whitening equation of the differential equation:

$$
\frac{d x^{(1)}}{d t}-0.110619605 \times x^{(1)}=482,266.0641 .
$$

Find the prediction model from

$$
\begin{gathered}
X^{(1)}(k+1)=\left(X^{(0)}(1)-\frac{b}{a}\right) e^{-a k}+\frac{b}{a} \\
X^{(1)}(k+1)=\left(455,117-\frac{482,266.0641}{-0.110619605}\right) e^{0.110619605}+\frac{482,266.0641}{-0.110619605} \\
=(4,814,796.860) e^{0.110619605}-4,359,679.806
\end{gathered}
$$

Substitute different values of $\mathrm{k}$ into the equation:

$$
\begin{array}{ll}
k=0 & X^{(1)}(1)=455,117 \\
k=1 & X^{(1)}(2)=1,018,303 \\
k=2 & X^{(1)}(3)=1,647,365 \\
k=3 & X^{(1)}(4)=2,350,009 \\
k=4 & X^{(1)}(5)=3,134,841 \\
k=5 & X^{(1)}(6)=4,011,475 \\
k=6 & X^{(1)}(7)=4,990,648 \\
k=7 & X^{(1)}(8)=6,084,356 \\
k=8 & X^{(1)}(9)=7,305,994 \\
k=9 & X^{(1)}(10)=8,670,527
\end{array}
$$

Derive the predicted value of the original series according to the accumulated generating operation and obtain

$$
\begin{aligned}
& \hat{x}^{(0)}(1)=x^{(1)}(1)=455,117-\text { for year } 2013 \\
& \hat{x}^{(0)}(2)=x^{(1)}(2)-x^{(1)}(1)=563,186-\text { for year } 2014 \\
& \hat{x}^{(0)}(3)=x^{(1)}(3)-x^{(1)}(2)=629,062-\text { for year } 2015 \\
& \hat{x}^{(0)}(4)=x^{(1)}(4)-x^{(1)}(3)=702,643-\text { for year } 2016 \\
& \hat{x}^{(0)}(5)=x^{(1)}(5)-x^{(1)}(4)=784,831-\text { for year } 2017 \\
& \hat{x}^{(0)}(6)=x^{(1)}(6)-x^{(1)}(5)=876,633-\text { for year } 2018 \\
& \hat{x}^{(0)}(7)=x^{(1)}(7)-x^{(1)}(6)=979,173-\text { for year } 2019 \\
& \hat{x}^{(0)}(8)=x^{(1)}(8)-x^{(1)}(7)=1,093,707-\text { for year } 2020 \\
& \hat{x}^{(0)}(9)=x^{(1)}(9)-x^{(1)}(8)=1,221,638-\text { for year } 2021 \\
& \hat{x}^{(0)}(10)=x^{(1)}(10)-x^{(1)}(9)=1,364,533-\text { for year } 2022
\end{aligned}
$$


The other input and output factors' forecasting results will be carried out same as the above process. The results of all DMUs from 2018 to 2022 could be acquired and the detailed numbers are generated in the table 4.1 to 4.5 respectively:

Table 4.1. Financial data of decision-making units 2018

\begin{tabular}{|c|c|c|c|c|c|c|c|}
\hline DENOTE & I (COGS) & $\begin{array}{c}\text { I (SALES } \\
\text { EXPENSES) }\end{array}$ & $\begin{array}{c}\text { I } \\
\text { (OPERATIO } \\
\text { N EXPENSE) }\end{array}$ & $\begin{array}{l}\text { I (EQUITY } \\
\text { CAPITAL) }\end{array}$ & $\begin{array}{c}\text { I (FIXED } \\
\text { ASSET) }\end{array}$ & $\begin{array}{c}\text { O } \\
\text { (REVENUE) }\end{array}$ & $\begin{array}{l}\text { O (PROFIT } \\
\text { AFTER TAX }\end{array}$ \\
\hline$\underline{\text { DMU1 }}$ & $32,908,616$ & $32,908,616$ & $32,908,616$ & $32,908,616$ & $32,908,616$ & $32,908,616$ & $32,908,616$ \\
\hline DMU2 & $13,478,159$ & 47,923 & 209,550 & $26,711,591$ & $41,077,064$ & $17,825,572$ & $2,639,877$ \\
\hline$\underline{\text { DMU3 }}$ & $76,576,376$ & 802,055 & 132,735 & $1,357,945$ & $5,424,210$ & 548,536 & $(2,160)$ \\
\hline$\underline{\text { DMU4 }}$ & 483,545 & 55,537 & 132,735 & $14,095,615$ & 582,156 & $17,757,563$ & 418,969 \\
\hline$\underline{\text { DMU5 }}$ & $9,162,200$ & 61,518 & 600,414 & $13,824,261$ & 705,966 & $8,950,675$ & 155,308 \\
\hline$\underline{\text { DMU6 }}$ & $6,060,193$ & $1,181,491$ & $1,029,223$ & $4,872,856$ & $3,765,479$ & $8,046,307$ & 335,272 \\
\hline$\underline{\text { DMU7 }}$ & 42,334 & 4,466 & 12,848 & $1,236,428$ & 1,948 & 34,135 & 15,871 \\
\hline$\underline{\text { DMU8 }}$ & $4,788,941$ & 992,087 & $3,287,557$ & $38,014,824$ & $8,803,001$ & $9,747,591$ & $4,601,632$ \\
\hline$\underline{\text { DMU9 }}$ & $28,121,728$ & $6,317,735$ & $12,613,506$ & $52,338,060$ & $58,484,432$ & $53,715,440$ & $(7,762,659)$ \\
\hline$\underline{\mathrm{DMU} 10}$ & $2,887,402$ & 17,091 & 222,029 & $6,591,606$ & $5,915,483$ & $3,456,240$ & 394,069 \\
\hline$\underline{\text { DMU11 }}$ & $1,193,309$ & - & 314,599 & $10,513,538$ & $1,820,995$ & $2,393,822$ & 992,115 \\
\hline DMU12 & $2,441,583$ & $1,720,458$ & 115,510 & $5,709,437$ & 501,977 & $4,605,586$ & 274,796 \\
\hline$\underline{\mathrm{DMU} 13}$ & $1,763,348$ & - & 692,579 & $3,960,691$ & $2,839,775$ & $2,782,695$ & 348,412 \\
\hline DMU14 & $37,453,279$ & 382,746 & $1,269,673$ & $8,568,309$ & $9,799,291$ & $12,423,095$ & 345,689 \\
\hline$\underline{\text { DMU15 }}$ & $3,334,348$ & $1,390,279$ & $2,425,122$ & $7,386,611$ & $5,098,755$ & $6,958,109$ & 9,656 \\
\hline$\underline{\text { DMU16 }}$ & $2,654,787$ & 38,652 & 360,443 & $3,260,395$ & $3,260,395$ & $7,124,050$ & $(28,570)$ \\
\hline$\underline{\text { DMU17 }}$ & $1,329,496$ & 130,241 & 263,803 & $2,339,723$ & $2,035,763$ & $1,850,575$ & 37,359 \\
\hline$\underline{\text { DMU18 }}$ & $9,886,471$ & $1,978,471$ & 626,407 & $3,988,739$ & $1,634,898$ & $12,610,975$ & 983,349 \\
\hline$\underline{\text { DMU19 }}$ & $9,886,471$ & $1,978,471$ & $2,007,085$ & $4,381,002$ & $1,634,898$ & $12,610,975$ & 531,090 \\
\hline DMU20 & $6,381,260$ & 23,930 & 329,038 & $1,655,251$ & 555,370 & $6,381,260$ & 291,194 \\
\hline
\end{tabular}


Table 4.2. Financial data of decision-making units 2019

\begin{tabular}{|l|l|l|l|l|l|l|l|}
\hline DENOTE & \multicolumn{1}{|c|}{ I (COGS) } & $\begin{array}{c}\text { I (SALES } \\
\text { EXPENSES) }\end{array}$ & $\begin{array}{c}\text { I } \\
\text { (OPERATIO } \\
\text { N EXPENSE) }\end{array}$ & $\begin{array}{l}\text { I (EQUITY } \\
\text { CAPITAL) }\end{array}$ & $\begin{array}{c}\text { I (FIXED } \\
\text { ASSET) }\end{array}$ & $\begin{array}{c}\text { O } \\
\text { (REVENUE) }\end{array}$ & $\begin{array}{l}\text { O (PROFIT } \\
\text { AFTER TAX }\end{array}$ \\
\hline$\underline{\text { DMU1 }}$ & $37,098,046$ & $1,890,424$ & $2,615,960$ & $11,466,654$ & $2,850,215$ & $42,572,760$ & 981,061 \\
\hline$\underline{\text { DMU2 }}$ & $21,412,310$ & 53,533 & 229,447 & $39,762,448$ & $57,698,449$ & $27,611,697$ & $4,412,162$ \\
\hline$\underline{\text { DMU3 }}$ & $68,177,527$ & 725,295 & 124,253 & $1,333,963$ & $5,484,919$ & 486,002 & $(2,272)$ \\
\hline$\underline{\text { DMU4 }}$ & 432,150 & 53,533 & 124,253 & $14,329,849$ & 649,092 & $19,072,378$ & 492,506 \\
\hline$\underline{\text { DMU5 }}$ & $12,158,274$ & 62,712 & 605,491 & $14,007,484$ & 678,952 & $9,033,212$ & 169,854 \\
\hline$\underline{\text { DMU6 }}$ & $6,229,626$ & $1,851,392$ & $1,252,261$ & $4,905,668$ & $3,618,884$ & $8,493,387$ & 278,994 \\
\hline$\underline{\text { DMU7 }}$ & 46,613 & 4,359 & 12,831 & $1,306,662$ & 656 & 32,394 & 16,405 \\
\hline$\underline{\text { DMU8 }}$ & $4,991,351$ & 976,854 & $3,225,616$ & $38,288,765$ & $6,531,108$ & $10,084,064$ & $7,736,101$ \\
\hline$\underline{\text { DMU9 }}$ & $31,027,610$ & $6,744,248$ & $13,857,607$ & $52,755,069$ & $62,891,546$ & $61,426,778$ & $(8,089,791)$ \\
\hline$\underline{\text { DMU10 }}$ & $2,964,553$ & 11,267 & 190,777 & $6,789,405$ & $5,928,333$ & $3,541,795$ & 609,336 \\
\hline$\underline{\text { DMU11 }}$ & $1,321,688$ & - & 317,410 & $15,698,135$ & $1,689,007$ & $2,854,516$ & $1,945,718$ \\
\hline$\underline{\text { DMU12 }}$ & $2,363,252$ & $1,829,433$ & 118,395 & $8,232,072$ & 441,592 & $4,616,801$ & 272,509 \\
\hline$\underline{\text { DMU13 }}$ & $1,797,353$ & - & 847,900 & $3,994,845$ & $2,770,284$ & $2,859,928$ & 327,333 \\
\hline$\underline{\text { DMU14 }}$ & $98,443,453$ & 506,905 & $1,456,691$ & $9,160,646$ & $10,956,611$ & $16,671,791$ & 498,003 \\
\hline$\underline{\text { DMU15 }}$ & $3,300,936$ & $1,449,366$ & $2,653,246$ & $7,303,900$ & $5,231,296$ & $7,135,472$ & 9,271 \\
\hline$\underline{\text { DMU16 }}$ & $2,627,426$ & 38,730 & 372,926 & $3,180,629$ & $3,180,629$ & $6,972,281$ & $(16,456)$ \\
\hline$\underline{\text { DMU17 }}$ & $1,402,484$ & 138,824 & 309,527 & $2,343,045$ & $2,024,305$ & $2,015,901$ & 42,898 \\
\hline$\underline{\text { DMU18 }}$ & $12,235,304$ & $2,016,607$ & 847,652 & $4,199,560$ & $1,530,489$ & $14,777,243$ & $1,220,173$ \\
\hline$\underline{\text { DMU19 }}$ & $12,235,304$ & $2,016,607$ & $2,054,724$ & $4,691,514$ & $1,530,489$ & $14,777,243$ & 590,032 \\
\hline$\underline{\text { DMU20 }}$ & $6,711,212$ & 24,138 & 218,970 & $1,385,341$ & 459,497 & $6,711,212$ & 241,473 \\
\hline
\end{tabular}


Table 4.3. Financial data of decision-making units 2020

\begin{tabular}{|c|c|c|c|c|c|c|c|}
\hline DENOTE & I (COGS) & $\begin{array}{c}\text { I (SALES } \\
\text { EXPENSES) }\end{array}$ & $\begin{array}{c}\text { I } \\
\text { (OPERATIO } \\
\text { N EXPENSE) }\end{array}$ & $\begin{array}{l}\text { I (EQUITY } \\
\text { CAPITAL) }\end{array}$ & $\begin{array}{c}\text { I (FIXED } \\
\text { ASSET) }\end{array}$ & $\begin{array}{c}\text { O } \\
\text { (REVENUE) }\end{array}$ & $\begin{array}{l}\text { O (PROFIT } \\
\text { AFTER TAX }\end{array}$ \\
\hline$\underline{\text { DMU1 }}$ & $41,820,811$ & $1,927,365$ & $2,826,492$ & $11,535,781$ & $2,705,067$ & $47,552,493$ & 972,973 \\
\hline$\underline{\text { DMU2 }}$ & $34,017,037$ & 59,799 & 251,234 & $59,189,743$ & $81,045,496$ & $42,770,341$ & $7,374,271$ \\
\hline$\underline{\mathrm{DMU} 3}$ & $60,699,858$ & 655,882 & 116,312 & $1,310,405$ & $5,546,309$ & 430,596 & $(2,390)$ \\
\hline$\underline{\text { DMU4 }}$ & 386,217 & 51,601 & 116,312 & $14,567,975$ & 723,724 & $20,484,545$ & 578,951 \\
\hline$\underline{\text { DMU5 }}$ & $16,134,074$ & 63,931 & 610,612 & $14,193,136$ & 652,972 & $9,116,510$ & 185,761 \\
\hline$\underline{\text { DMU6 }}$ & $6,403,796$ & $2,901,122$ & $1,523,632$ & $4,938,702$ & $3,477,997$ & $8,965,309$ & 232,162 \\
\hline$\underline{\text { DMU7 }}$ & 51,325 & 4,254 & 12,813 & $1,380,886$ & 221 & 30,741 & 16,957 \\
\hline$\underline{\text { DMU8 }}$ & $5,202,316$ & 961,855 & $3,164,843$ & $38,564,681$ & $4,845,548$ & $10,432,152$ & $13,005,660$ \\
\hline$\underline{\text { DMU9 }}$ & $34,233,763$ & $7,199,555$ & $15,224,416$ & $53,175,401$ & $67,630,760$ & $70,245,150$ & $(8,430,709)$ \\
\hline$\underline{\text { DMU10 }}$ & $3,043,766$ & 7,427 & 163,924 & $6,993,140$ & $5,941,210$ & $3,629,468$ & 942,196 \\
\hline$\underline{\text { DMU11 }}$ & $1,463,879$ & - & 320,246 & $23,439,442$ & $1,566,584$ & $3,403,871$ & $3,815,907$ \\
\hline$\underline{\text { DMU12 }}$ & $2,287,434$ & $1,945,311$ & 121,351 & $11,869,299$ & 388,472 & $4,628,044$ & 270,242 \\
\hline$\underline{\text { DMU13 }}$ & $1,832,013$ & - & $1,038,055$ & $4,029,293$ & $2,702,493$ & $2,939,305$ & 307,529 \\
\hline$\underline{\text { DMU14 }}$ & $258,752,069$ & 671,340 & $1,671,255$ & $9,793,932$ & $12,250,612$ & $22,373,540$ & 717,427 \\
\hline$\underline{\text { DMU15 }}$ & $3,267,857$ & $1,510,964$ & $2,902,829$ & $7,222,116$ & $5,367,283$ & $7,317,356$ & 8,901 \\
\hline$\underline{\text { DMU16 }}$ & $2,600,346$ & 38,808 & 385,840 & $3,102,814$ & $3,102,814$ & $6,823,745$ & $(9,479)$ \\
\hline$\underline{\text { DMU17 }}$ & $1,479,478$ & 147,973 & 363,177 & $2,346,372$ & $2,012,912$ & $2,195,997$ & 49,259 \\
\hline$\underline{\text { DMU18 }}$ & $15,142,176$ & $2,055,478$ & $1,147,038$ & $4,421,524$ & $1,432,748$ & $17,315,624$ & $1,514,033$ \\
\hline$\underline{\text { DMU19 }}$ & $15,142,176$ & $2,055,478$ & $2,103,495$ & $5,024,033$ & $1,432,748$ & $17,315,624$ & 655,516 \\
\hline$\underline{\text { DMU20 }}$ & $7,058,225$ & 24,348 & 145,722 & $1,159,444$ & 380,174 & $7,058,225$ & 200,241 \\
\hline
\end{tabular}


Table 4.4. Financial data of decision making units 2021

\begin{tabular}{|c|c|c|c|c|c|c|c|}
\hline DENOTE & I (COGS) & $\begin{array}{c}\text { I (SALES } \\
\text { EXPENSES) }\end{array}$ & $\begin{array}{c}\text { I } \\
\text { (OPERATIO } \\
\text { N EXPENSE) }\end{array}$ & $\begin{array}{l}\text { I (EQUITY } \\
\text { CAPITAL) }\end{array}$ & $\begin{array}{c}\text { I (FIXED } \\
\text { ASSET) }\end{array}$ & $\begin{array}{c}\text { O } \\
\text { (REVENUE) }\end{array}$ & $\begin{array}{l}\text { O (PROFIT } \\
\text { AFTER TAX }\end{array}$ \\
\hline$\underline{\text { DMU1 }}$ & $47,144,808$ & $1,965,028$ & $3,053,969$ & $11,605,324$ & $2,567,311$ & $53,114,705$ & 964,952 \\
\hline$\underline{\text { DMU2 }}$ & $54,041,754$ & 66,798 & 275,089 & $88,108,905$ & $113,839,670$ & $66,250,982$ & $12,324,995$ \\
\hline$\underline{\mathrm{DMU} 3}$ & $54,042,336$ & 593,112 & 108,879 & $1,287,264$ & $5,608,385$ & 381,507 & $(2,514)$ \\
\hline$\underline{\text { DMU4 }}$ & 345,167 & 49,738 & 108,879 & $14,810,058$ & 806,937 & $22,001,272$ & 680,569 \\
\hline$\underline{\text { DMU5 }}$ & $21,409,977$ & 65,172 & 615,775 & $14,381,248$ & 627,985 & $9,200,576$ & 203,158 \\
\hline$\underline{\text { DMU6 }}$ & $6,582,836$ & $4,546,045$ & $1,853,810$ & $4,971,958$ & $3,342,594$ & $9,463,452$ & 193,192 \\
\hline$\underline{\text { DMU7 }}$ & 56,514 & 4,151 & 12,796 & $1,459,326$ & 74 & 29,173 & 17,528 \\
\hline$\underline{\text { DMU8 }}$ & $5,422,198$ & 947,087 & $3,105,214$ & $38,842,585$ & $3,595,001$ & $10,792,256$ & $21,864,655$ \\
\hline$\underline{\text { DMU9 }}$ & $37,771,215$ & $7,685,600$ & $16,726,037$ & $53,599,081$ & $72,727,100$ & $80,329,479$ & $(8,785,994)$ \\
\hline$\underline{\text { DMU10 }}$ & $3,125,096$ & 4,896 & 140,851 & $7,202,988$ & $5,954,115$ & $3,719,311$ & $1,456,888$ \\
\hline$\underline{\text { DMU11 }}$ & $1,621,367$ & - & 323,107 & $34,998,261$ & $1,453,036$ & $4,058,950$ & $7,483,687$ \\
\hline$\underline{\text { DMU12 }}$ & $2,214,048$ & $2,068,528$ & 124,381 & $17,113,585$ & 341,741 & $4,639,314$ & 267,993 \\
\hline$\underline{\text { DMU13 }}$ & $1,867,341$ & - & $1,270,854$ & $4,064,038$ & $2,636,362$ & $3,020,885$ & 288,923 \\
\hline$\underline{\text { DMU14 }}$ & $680,112,603$ & 889,116 & $1,917,424$ & $10,470,997$ & $13,697,439$ & $30,025,286$ & $1,033,533$ \\
\hline$\underline{\text { DMU15 }}$ & $3,235,111$ & $1,575,181$ & $3,175,889$ & $7,141,247$ & $5,506,805$ & $7,503,876$ & 8,545 \\
\hline$\underline{\text { DMU16 }}$ & $2,573,546$ & 38,887 & 399,202 & $3,026,902$ & $3,026,902$ & $6,678,373$ & $(5,460)$ \\
\hline$\underline{\text { DMU17 }}$ & $1,560,700$ & 157,725 & 426,126 & $2,349,704$ & $2,001,582$ & $2,392,183$ & 56,563 \\
\hline$\underline{\text { DMU18 }}$ & $18,739,663$ & $2,095,099$ & $1,552,167$ & $4,655,220$ & $1,341,249$ & $20,290,038$ & $1,878,664$ \\
\hline$\underline{\text { DMU19 }}$ & $18,739,663$ & $2,095,099$ & $2,153,422$ & $5,380,121$ & $1,341,249$ & $20,290,038$ & 728,268 \\
\hline$\underline{\text { DMU20 }}$ & $7,423,180$ & 24,560 & 96,976 & 970,383 & 314,545 & $7,423,180$ & 166,050 \\
\hline
\end{tabular}


Table 4.5. Financial data of decision making units 2022

\begin{tabular}{|c|c|c|c|c|c|c|c|}
\hline DENOTE & I (COGS) & $\begin{array}{l}\text { I (SALES } \\
\text { EXPENSES) }\end{array}$ & $\begin{array}{c}\text { I } \\
\text { (OPERATIO } \\
\text { N EXPENSE) }\end{array}$ & $\begin{array}{l}\text { I (EQUITY } \\
\text { CAPITAL) }\end{array}$ & $\begin{array}{r}\text { I (FIXED } \\
\text { ASSET) }\end{array}$ & $\begin{array}{c}\text { O } \\
\text { (REVENUE) }\end{array}$ & $\begin{array}{r}\text { O (PROFIT } \\
\text { AFTER TAX }\end{array}$ \\
\hline$\underline{\text { DMU1 }}$ & $53,146,575$ & $2,003,427$ & $3,299,752$ & $11,675,287$ & $2,436,571$ & $59,327,529$ & 956,998 \\
\hline$\underline{\text { DMU2 }}$ & $85,854,367$ & 74,616 & 301,210 & $131,157,506$ & $159,903,649$ & $102,622,345$ & $20,599,393$ \\
\hline$\underline{\mathrm{DMU} 3}$ & $48,115,006$ & 536,350 & 101,921 & $1,264,531$ & $5,671,156$ & 338,014 & $(2,644)$ \\
\hline$\underline{\text { DMU4 }}$ & 308,480 & 47,944 & 101,921 & $15,056,164$ & 899,718 & $23,630,302$ & 800,023 \\
\hline$\underline{\text { DMU5 }}$ & $28,411,119$ & 66,438 & 620,983 & $14,571,854$ & 603,955 & $9,285,418$ & 222,185 \\
\hline$\underline{\text { DMU6 }}$ & $6,766,881$ & $7,123,632$ & $2,255,540$ & $5,005,438$ & $3,212,462$ & $9,989,274$ & 160,763 \\
\hline$\underline{\text { DMU7 }}$ & 62,226 & 4,051 & 12,779 & $1,542,221$ & 25 & 27,684 & 18,118 \\
\hline$\underline{\text { DMU8 }}$ & $5,651,373$ & 932,545 & $3,046,709$ & $39,122,491$ & $2,667,197$ & $11,164,790$ & $36,758,085$ \\
\hline$\underline{\text { DMU9 }}$ & $41,674,200$ & $8,204,458$ & $18,375,766$ & $54,026,138$ & $78,207,476$ & $91,861,505$ & $(9,156,251)$ \\
\hline$\underline{\text { DMU10 }}$ & $3,208,598$ & 3,228 & 121,025 & $7,419,133$ & $5,967,049$ & $3,811,379$ & $2,252,739$ \\
\hline$\underline{\text { DMU11 }}$ & $1,795,798$ & - & 325,994 & $52,257,143$ & $1,347,717$ & $4,840,100$ & $14,676,872$ \\
\hline$\underline{\text { DMU12 }}$ & $2,143,017$ & $2,199,551$ & 127,487 & $24,674,985$ & 300,631 & $4,650,612$ & 265,763 \\
\hline$\underline{\text { DMU13 }}$ & $1,903,351$ & - & $1,555,863$ & $4,099,082$ & $2,571,848$ & $3,104,729$ & 271,442 \\
\hline$\underline{\text { DMU14 }}$ & $\begin{array}{l}1,787,630,73 \\
8\end{array}$ & $1,177,536$ & $2,199,853$ & $11,194,869$ & $15,315,139$ & $40,293,928$ & $1,488,917$ \\
\hline$\underline{\text { DMU15 }}$ & $3,202,692$ & $1,642,127$ & $3,474,635$ & $7,061,284$ & $5,649,953$ & $7,695,151$ & 8,204 \\
\hline$\underline{\text { DMU16 }}$ & $2,547,022$ & 38,966 & 413,027 & $2,952,848$ & $2,952,848$ & $6,536,099$ & $(3,145)$ \\
\hline$\underline{\text { DMU17 }}$ & $1,646,380$ & 168,119 & 499,985 & $2,353,041$ & $1,990,317$ & $2,605,895$ & 64,950 \\
\hline$\underline{\text { DMU18 }}$ & $23,191,844$ & $2,135,483$ & $2,100,385$ & $4,901,267$ & $1,255,593$ & $23,775,387$ & $2,331,112$ \\
\hline$\underline{\text { DMU19 }}$ & $23,191,844$ & $2,135,483$ & $2,204,535$ & $5,761,447$ & $1,255,593$ & $23,775,387$ & 809,093 \\
\hline$\underline{\text { DMU20 }}$ & $7,807,007$ & 24,774 & 64,536 & 812,150 & 260,245 & $7,807,007$ & 137,697 \\
\hline
\end{tabular}

Because the smallest value is - 9,156,251 USD which is forecast value of factor profit after tax of DMU9, all values will be scale up USD10,000,000 for carrying the DEA model. 


\subsection{Forecasting Accuracy}

The predicting data of DMUs for next 5 years from 2018 to 2022 generated by GM $(1,1)$ model is used as inputs for DEA - Malmquist to study the performance of them in future. Since the study mentioned in previous chapter, forecasting data should be accuracy to ensure that result of future data and upcoming analysis. Therefore, MAPE (Mean Absolut Percentage Error) is employed to calculate forecasting error between the two sets of data. The results are summarized in the following table:

Table 4. 1 MAPE 2013-2017

\begin{tabular}{|l|l|r|}
\hline Denote & DMU & Average MAPE (\%) \\
\hline BTV & DMU1 & $5.16 \%$ \\
\hline DAH & DMU2 & $11.30 \%$ \\
\hline DCD & DMU3 & $15.06 \%$ \\
\hline DXL & DMU4 & $9.50 \%$ \\
\hline EIN & DMU5 & $10.40 \%$ \\
\hline HOT & DMU6 & $5.65 \%$ \\
\hline NPH & DMU7 & $10.76 \%$ \\
\hline NVT & DMU8 & $13.43 \%$ \\
\hline OCH & DMU9 & $10.49 \%$ \\
\hline PDC & DMU10 & $12.46 \%$ \\
\hline SGH & DMU11 & $9.06 \%$ \\
\hline TTJ & DMU12 & $5.71 \%$ \\
\hline VIR & DMU13 & $2.65 \%$ \\
\hline VNG & DMU14 & $12.68 \%$ \\
\hline VTG & DMU15 & $1.72 \%$ \\
\hline DLD & DMU16 & $2.05 \%$ \\
\hline MTC & DMU17 & $2.46 \%$ \\
\hline OSCVN & DMU18 & $2.96 \%$ \\
\hline DNT & DMU19 & $1.78 \%$ \\
\hline KimLien & MMU20 & \\
\hline & & DMPE \\
\hline
\end{tabular}

The result of average MAPE is only 7.75 which proves that $\mathrm{G}(1,1)$ model is qualified to apply to forecast the future value of DMUs in this research. 


\subsection{Pearson Correlation}

The Pearson correlation is conducted to confirm the relationship between input and output. Pearson test confirms that the lower correlation implies the less correlated and higher correlation implies the closer correlated between two variables. The correlation value is always from -1 to 1 . The closer to -1 and 1 is correlation, the more perfect is linear relationship formed.

Tables from 4.6 to 4.15 confirm that the correlations comply well with the earlier condition of the DEA model as their correlation coefficients show strong positive associations. Hence, it proves that the input and output are chosen appropriately. And there is no elimination of any variable.

Table 4. 6. Correlation coefficient 2013

\begin{tabular}{|c|c|c|c|c|c|c|c|}
\hline & COGS & $\begin{array}{l}\text { SALES } \\
\text { EXPENSES }\end{array}$ & $\begin{array}{l}\text { OPERATION } \\
\text { EXPENSE }\end{array}$ & $\begin{array}{l}\text { EQUITY } \\
\text { CAPITAL }\end{array}$ & $\begin{array}{l}\text { FIXED } \\
\text { ASSET }\end{array}$ & REVENUE & $\begin{array}{l}\text { PROFIT } \\
\text { AFTER TAX }\end{array}$ \\
\hline COGS & 1.0000 & 0.2600 & 0.0118 & 0.0402 & 0.0911 & 0.0198 & 0.1703 \\
\hline $\begin{array}{l}\text { SALES } \\
\text { EXPENSES }\end{array}$ & 0.2600 & 1.0000 & 0.7352 & 0.8324 & 0.7104 & 0.8123 & 0.8735 \\
\hline $\begin{array}{l}\text { OPERATION } \\
\text { EXPENSE }\end{array}$ & 0.0118 & 0.7352 & 1.0000 & 0.8156 & 0.7452 & 0.8539 & 0.8434 \\
\hline $\begin{array}{l}\text { EQUITY } \\
\text { CAPITAL }\end{array}$ & 0.0402 & 0.8324 & 0.8156 & 1.0000 & 0.8850 & 0.8381 & 0.8921 \\
\hline FIXED ASSET & 0.0911 & 0.7104 & 0.7452 & 0.8850 & 1.0000 & 0.6227 & 0.7515 \\
\hline REVENUE & 0.0198 & 0.8123 & 0.8539 & 0.8381 & 0.6227 & 1.0000 & 0.9156 \\
\hline $\begin{array}{l}\text { PROFIT } \\
\text { AFTER TAX }\end{array}$ & 0.1703 & 0.8735 & 0.8434 & 0.8921 & 0.7515 & 0.9156 & 1.0000 \\
\hline
\end{tabular}


Table 4. 7. Correlation coefficient 2014

\begin{tabular}{|c|c|c|c|c|c|c|c|}
\hline & COGS & $\begin{array}{l}\text { SALES } \\
\text { EXPENSES }\end{array}$ & $\begin{array}{l}\text { OPERATION } \\
\text { EXPENSE }\end{array}$ & $\begin{array}{l}\text { EQUITY } \\
\text { CAPITAL }\end{array}$ & $\begin{array}{l}\text { FIXED } \\
\text { ASSET }\end{array}$ & REVENUE & $\begin{array}{l}\text { PROFIT } \\
\text { AFTER TAX }\end{array}$ \\
\hline COGS & 1.0000 & 0.2343 & 0.0904 & -0.0025 & 0.1016 & 0.0505 & -0.1021 \\
\hline $\begin{array}{l}\text { SALES } \\
\text { EXPENSES }\end{array}$ & 0.2343 & 1.0000 & 0.8323 & 0.6870 & 0.6726 & 0.8217 & -0.7957 \\
\hline $\begin{array}{l}\text { OPERATION } \\
\text { EXPENSE }\end{array}$ & 0.0904 & 0.8323 & 1.0000 & 0.8062 & 0.8456 & 0.7739 & -0.9894 \\
\hline $\begin{array}{l}\text { EQUITY } \\
\text { CAPITAL }\end{array}$ & -0.0025 & 0.6870 & 0.8062 & 1.0000 & 0.8333 & 0.7424 & -0.7460 \\
\hline FIXED ASSET & 0.1016 & 0.6726 & 0.8456 & 0.8333 & 1.0000 & 0.6132 & -0.8230 \\
\hline REVENUE & 0.0505 & 0.8217 & 0.7739 & 0.7424 & 0.6132 & 1.0000 & -0.7203 \\
\hline $\begin{array}{l}\text { PROFIT } \\
\text { AFTER TAX }\end{array}$ & -0.1021 & -0.7957 & -0.9894 & -0.7460 & -0.8230 & -0.7203 & 1.0000 \\
\hline
\end{tabular}

Table 4. 8. Correlation coefficient 2015

\begin{tabular}{|c|c|c|c|c|c|c|c|}
\hline & COGS & $\begin{array}{l}\text { SALES } \\
\text { EXPENSES }\end{array}$ & $\begin{array}{l}\text { OPERATION } \\
\text { EXPENSE }\end{array}$ & $\begin{array}{l}\text { EQUITY } \\
\text { CAPITAL }\end{array}$ & $\begin{array}{l}\text { FIXED } \\
\text { ASSET }\end{array}$ & REVENUE & $\begin{array}{l}\text { PROFIT } \\
\text { AFTER TAX }\end{array}$ \\
\hline COGS & 1.0000 & 0.2107 & -0.0014 & -0.0277 & 0.0483 & 0.0105 & 0.0769 \\
\hline $\begin{array}{l}\text { SALES } \\
\text { EXPENSES }\end{array}$ & 0.2107 & 1.0000 & 0.8204 & 0.6763 & 0.6628 & 0.6466 & 0.1385 \\
\hline $\begin{array}{l}\text { PERATION } \\
\text { EXPENSE }\end{array}$ & -0.0014 & 0.8204 & 1.0000 & 0.9400 & 0.8725 & 0.6454 & -0.2134 \\
\hline $\begin{array}{l}\text { EQUITY } \\
\text { CAPITAL }\end{array}$ & -0.0277 & 0.6763 & 0.9400 & 1.0000 & 0.8499 & 0.6655 & -0.3462 \\
\hline FIXED ASSET & 0.0483 & 0.6628 & 0.8725 & 0.8499 & 1.0000 & 0.4731 & -0.1748 \\
\hline REVENUE & 0.0105 & 0.6466 & 0.6454 & 0.6655 & 0.4731 & 1.0000 & 0.2546 \\
\hline $\begin{array}{l}\text { PROFIT } \\
\text { AFTER TAX }\end{array}$ & 0.0769 & 0.1385 & -0.2134 & -0.3462 & -0.1748 & 0.2546 & 1.0000 \\
\hline
\end{tabular}


Table 4. 9. Correlation coefficient 2016

\begin{tabular}{|l|l|l|l|l|l|l|l|}
\hline & COGS & $\begin{array}{l}\text { SALES } \\
\text { EXPENSES }\end{array}$ & $\begin{array}{l}\text { PERATION } \\
\text { EXPENSE }\end{array}$ & $\begin{array}{l}\text { EQUITY } \\
\text { CAPITAL }\end{array}$ & $\begin{array}{l}\text { IXED } \\
\text { ASSET }\end{array}$ & REVENUE & $\begin{array}{l}\text { PROFIT } \\
\text { AFTER TAX }\end{array}$ \\
\hline COGS & 1.0000 & 0.2970 & 0.1834 & 0.0597 & 0.1903 & 0.1770 & -0.2140 \\
\hline $\begin{array}{l}\text { SALES } \\
\text { EXPENSES }\end{array}$ & 0.2970 & 1.0000 & 0.8827 & 0.6186 & 0.6957 & 0.7956 & -0.7954 \\
\hline $\begin{array}{l}\text { PERATION } \\
\text { EXPENSE }\end{array}$ & 0.1834 & 0.8827 & 1.0000 & 0.8139 & 0.8506 & 0.8320 & -0.8946 \\
\hline $\begin{array}{l}\text { EQUITY } \\
\text { CAPITAL }\end{array}$ & 0.0597 & 0.6186 & 0.8139 & 1.0000 & 0.8293 & 0.7135 & -0.6195 \\
\hline $\begin{array}{l}\text { FIXED ASSET } \\
\text { REVENUE }\end{array}$ & 0.1903 & 0.6957 & 0.8506 & 0.8293 & 1.0000 & 0.6900 & -0.7823 \\
\hline $\begin{array}{l}\text { PROFIT } \\
\text { AFTER TAX }\end{array}$ & -0.2140 & -0.7954 & -0.8946 & -0.6195 & -0.7823 & -0.6654 & 1.0000 \\
\hline
\end{tabular}

Table 4. 10. Correlation coefficient 2017

\begin{tabular}{|l|l|l|l|l|l|l|l|}
\hline & COGS & $\begin{array}{c}\text { SALES } \\
\text { EXPENSES }\end{array}$ & $\begin{array}{l}\text { PERATION } \\
\text { EXPENSE }\end{array}$ & $\begin{array}{l}\text { EQUITY } \\
\text { CAPITAL }\end{array}$ & $\begin{array}{l}\text { IXED } \\
\text { ASSET }\end{array}$ & REVENUE & $\begin{array}{l}\text { PROFIT } \\
\text { AFTER TAX }\end{array}$ \\
\hline COGS & 1.0000 & 0.2738 & 0.0782 & 0.1658 & 0.2289 & 0.2283 & -0.0705 \\
\hline $\begin{array}{l}\text { SALES } \\
\text { EXPENSES }\end{array}$ & 0.2738 & 1.0000 & 0.5854 & 0.6972 & 0.7026 & 0.7681 & 0.0229 \\
\hline $\begin{array}{l}\text { PERATION } \\
\text { EXPENSE }\end{array}$ & 0.0782 & 0.5854 & 1.0000 & 0.6625 & 0.6444 & 0.5513 & 0.7644 \\
\hline $\begin{array}{l}\text { EQUITY } \\
\text { CAPITAL }\end{array}$ & 0.1658 & 0.6972 & 0.6625 & 1.0000 & 0.9313 & 0.8728 & 0.1421 \\
\hline $\begin{array}{l}\text { FIXED ASSET } \\
\text { REVENUE }\end{array}$ & 0.2289 & 0.7026 & 0.6444 & 0.9313 & 1.0000 & 0.7571 & 0.1400 \\
\hline $\begin{array}{l}\text { PROFIT } \\
\text { AFTER TAX }\end{array}$ & -0.0705 & 0.0229 & 0.7644 & 0.1421 & 0.1400 & 0.0368 & 1.0000 \\
\hline
\end{tabular}


Table 4.11. Correlation coefficient 2018

\begin{tabular}{|l|l|l|l|l|l|l|l|}
\hline & COGS & $\begin{array}{l}\text { SALES } \\
\text { EXPENSES }\end{array}$ & $\begin{array}{l}\text { PERATION } \\
\text { EXPENSE }\end{array}$ & $\begin{array}{l}\text { EQUITY } \\
\text { CAPITAL }\end{array}$ & $\begin{array}{l}\text { IXED } \\
\text { ASSET }\end{array}$ & REVENUE & $\begin{array}{l}\text { PROFIT } \\
\text { AFTER TAX }\end{array}$ \\
\hline COGS & 1.0000 & 0.2980 & 0.3054 & 0.1616 & 0.3360 & 0.2457 & 0.1812 \\
\hline $\begin{array}{l}\text { SALES } \\
\text { EXPENSES }\end{array}$ & 0.2980 & 1.0000 & 0.9777 & 0.4537 & 0.4661 & 0.5485 & 0.8969 \\
\hline $\begin{array}{l}\text { PERATION } \\
\text { EXPENSE }\end{array}$ & 0.3054 & 0.9777 & 1.0000 & 0.5956 & 0.5894 & 0.6744 & 0.8136 \\
\hline $\begin{array}{l}\text { EQUITY } \\
\text { CAPITAL }\end{array}$ & 0.1616 & 0.4537 & 0.5956 & 1.0000 & 0.8376 & 0.8329 & 0.2441 \\
\hline $\begin{array}{l}\text { FIXED ASSET } \\
\text { REVENUE }\end{array}$ & 0.3360 & 0.4661 & 0.5894 & 0.8376 & 1.0000 & 0.8638 & 0.1923 \\
\hline $\begin{array}{l}\text { PROFIT } \\
\text { AFTER TAX }\end{array}$ & 0.1812 & 0.8969 & 0.8136 & 0.2441 & 0.1923 & 0.2097 & 1.0000 \\
\hline
\end{tabular}

Table 4. 12. Correlation coefficient 2019

\begin{tabular}{|l|l|l|l|l|l|l|l|}
\hline & COGS & $\begin{array}{l}\text { SALES } \\
\text { EXPENSES }\end{array}$ & $\begin{array}{l}\text { PERATION } \\
\text { EXPENSE }\end{array}$ & $\begin{array}{l}\text { EQUITY } \\
\text { CAPITAL }\end{array}$ & $\begin{array}{l}\text { IXED } \\
\text { ASSET }\end{array}$ & REVENUE & $\begin{array}{l}\text { PROFIT } \\
\text { AFTER TAX }\end{array}$ \\
\hline COGS & 1.0000 & 0.1606 & 0.1695 & 0.0740 & 0.2340 & 0.2927 & -0.1422 \\
\hline $\begin{array}{l}\text { SALES } \\
\text { EXPENSES }\end{array}$ & 0.1606 & 1.0000 & 0.9058 & 0.5273 & 0.5455 & 0.7524 & -0.6269 \\
\hline $\begin{array}{l}\text { PERATION } \\
\text { EXPENSE }\end{array}$ & 0.1695 & 0.9058 & 1.0000 & 0.6972 & 0.6597 & 0.7924 & -0.6064 \\
\hline $\begin{array}{l}\text { EQUITY } \\
\text { CAPITAL }\end{array}$ & 0.0740 & 0.5273 & 0.6972 & 1.0000 & 0.8241 & 0.6996 & -0.0339 \\
\hline $\begin{array}{l}\text { FIXED ASSET } \\
\text { REVENUE }\end{array}$ & 0.2340 & 0.5455 & 0.6597 & 0.8241 & 1.0000 & 0.7172 & -0.3054 \\
\hline $\begin{array}{l}\text { PROFIT } \\
\text { AFTER TAX }\end{array}$ & -0.1422 & -0.6269 & -0.6064 & -0.0339 & -0.3054 & -0.4332 & 1.0000 \\
\hline
\end{tabular}


Table 4. 13. Correlation coefficient 2020

\begin{tabular}{|l|l|l|l|l|l|l|l|}
\hline & COGS & $\begin{array}{l}\text { SALES } \\
\text { EXPENSES }\end{array}$ & $\begin{array}{l}\text { PERATION } \\
\text { EXPENSE }\end{array}$ & $\begin{array}{l}\text { EQUITY } \\
\text { CAPITAL }\end{array}$ & $\begin{array}{l}\text { IXED } \\
\text { ASSET }\end{array}$ & REVENUE & $\begin{array}{l}\text { PROFIT } \\
\text { AFTER TAX }\end{array}$ \\
\hline COGS & 1.0000 & 0.0376 & 0.0861 & 0.0304 & 0.1510 & 0.2398 & -0.0629 \\
\hline $\begin{array}{l}\text { SALES } \\
\text { EXPENSES }\end{array}$ & 0.0376 & 1.0000 & 0.8935 & 0.3862 & 0.4328 & 0.6811 & -0.5096 \\
\hline $\begin{array}{l}\text { PERATION } \\
\text { EXPENSE }\end{array}$ & 0.0861 & 0.8935 & 1.0000 & 0.5470 & 0.5512 & 0.7493 & -0.4604 \\
\hline $\begin{array}{l}\text { EQUITY } \\
\text { CAPITAL }\end{array}$ & 0.0304 & 0.3862 & 0.5470 & 1.0000 & 0.8510 & 0.6913 & 0.2533 \\
\hline $\begin{array}{l}\text { FIXED ASSET } \\
\text { REVENUE }\end{array}$ & 0.1510 & 0.4328 & 0.5512 & 0.8510 & 1.0000 & 0.7468 & -0.0658 \\
\hline $\begin{array}{l}\text { PROFIT } \\
\text { AFTER TAX }\end{array}$ & -0.0629 & -0.5096 & -0.4604 & 0.2533 & -0.0658 & -0.2555 & 1.0000 \\
\hline
\end{tabular}

Table 4. 14. Correlation coefficient 2021

\begin{tabular}{|l|l|l|l|l|l|l|l|}
\hline & COGS & $\begin{array}{l}\text { SALES } \\
\text { EXPENSES }\end{array}$ & $\begin{array}{l}\text { PERATION } \\
\text { EXPENSE }\end{array}$ & $\begin{array}{l}\text { EQUITY } \\
\text { CAPITAL }\end{array}$ & $\begin{array}{l}\text { IXED } \\
\text { ASSET }\end{array}$ & REVENUE & $\begin{array}{l}\text { PROFIT } \\
\text { AFTER TAX }\end{array}$ \\
\hline COGS & 1.0000 & -0.0101 & 0.0399 & -0.0058 & 0.0874 & 0.2049 & -0.0409 \\
\hline $\begin{array}{l}\text { SALES } \\
\text { EXPENSES }\end{array}$ & -0.0101 & 1.0000 & 0.8530 & 0.2162 & 0.3065 & 0.5597 & -0.3953 \\
\hline $\begin{array}{l}\text { PERATION } \\
\text { EXPENSE }\end{array}$ & 0.0399 & 0.8530 & 1.0000 & 0.3708 & 0.4389 & 0.6768 & -0.3315 \\
\hline $\begin{array}{l}\text { EQUITY } \\
\text { CAPITAL }\end{array}$ & -0.0058 & 0.2162 & 0.3708 & 1.0000 & 0.8758 & 0.6976 & 0.4465 \\
\hline $\begin{array}{l}\text { FIXED ASSET } \\
\text { REVENUE }\end{array}$ & 0.0874 & 0.3065 & 0.4389 & 0.8758 & 1.0000 & 0.7912 & 0.1196 \\
\hline $\begin{array}{l}\text { PROFIT } \\
\text { AFTER TAX }\end{array}$ & -0.0409 & -0.3953 & -0.3315 & 0.4465 & 0.1196 & -0.0761 & 1.0000 \\
\hline
\end{tabular}


Table 4. 15. Correlation coefficient 2022

\begin{tabular}{|l|l|l|l|l|l|l|l|}
\hline & COGS & $\begin{array}{l}\text { SALES } \\
\text { EXPENSES }\end{array}$ & $\begin{array}{l}\text { PERATION } \\
\text { EXPENSE }\end{array}$ & $\begin{array}{l}\text { EQUITY } \\
\text { CAPITAL }\end{array}$ & $\begin{array}{l}\text { IXED } \\
\text { ASSET }\end{array}$ & REVENUE & $\begin{array}{l}\text { PROFIT } \\
\text { AFTER TAX }\end{array}$ \\
\hline COGS & 1.0000 & -0.0164 & 0.0227 & -0.0297 & 0.0480 & 0.1919 & -0.0448 \\
\hline $\begin{array}{l}\text { SALES } \\
\text { EXPENSES }\end{array}$ & -0.0164 & 1.0000 & 0.7701 & 0.0648 & 0.1816 & 0.3946 & -0.3049 \\
\hline $\begin{array}{l}\text { PERATION } \\
\text { EXPENSE }\end{array}$ & 0.0227 & 0.7701 & 1.0000 & 0.2107 & 0.3329 & 0.5756 & -0.2408 \\
\hline $\begin{array}{l}\text { EQUITY } \\
\text { CAPITAL }\end{array}$ & -0.0297 & 0.0648 & 0.2107 & 1.0000 & 0.8907 & 0.7249 & 0.5323 \\
\hline $\begin{array}{l}\text { FIXED ASSET } \\
\text { REVENUE }\end{array}$ & 0.0480 & 0.1816 & 0.3329 & 0.8907 & 1.0000 & 0.8434 & 0.2355 \\
\hline $\begin{array}{l}\text { PROFIT } \\
\text { AFTER TAX }\end{array}$ & -0.0448 & -0.3049 & -0.2408 & 0.5323 & 0.2355 & 0.0708 & 1.0000 \\
\hline
\end{tabular}

\section{Conclusion}

In conclusion, the research employs DEA Model and Malmquist Production Index model to study and evaluate performance of past-to-future performance of 20-listed company in Vietnam hospitality industry. At beginning, researcher collects data of 20 qualified listed companies (Decision Making Unit) with 2 sets of data: the original set of data and the future set of data. The original set of data is collected on vietstock.vn, cophieu68.com and website of companies where their financial reports are audited by reliable institution. The researcher uses 5 input variables (Cost of good sales; sales expense; operation expense; fixed assets and owner equity) and 2 output variables (Revenues and Profit after tax). The association level of those variables is examined by Pearson Correlation and the result confirms the close correlated relationship among variables which is qualified to the requirement of DEA model. Then DEA-Malmquist is applied first time to analysis the original data set (past data from 2013 to 2017) in order to evaluate performance of DMUs in the past. Next, the future data set is generated by employed GM $(1,1)$. The error of forecasting model is calculated by Mean Absolute Percentage Error (MAPE). The average MAPE of all DMUs is 7.75\% which is in acceptant range (less than 10\%). The forecast data will be input for DEA-Malmquist model to evaluate performance of DMUs in next 5 year from 2018 to 2022. 
In the first-time employing DEA model with the past data, the average score of all DMUs is 1.053 score. The most efficient company is DMU1 (average score is 1.053), however, it inconsistently performs during studying period. In the first two period of time from 2013 to 2015, DMU1 (BTV) has the highest score 1.051 and 1.140 respectively. In the other hand, DMU8 (NVT) is the least efficient firm from 2014 to 2015. Ninh Van Tourist experienced loss in period time from 2014 to 2015 due to their huge investment to real estate investment and development, but the real estate market was in deep crisis at that time. Together with the down trend of the world economy, Ninh Van Tourist made consecutive losses. Interestingly, period of year 2015 to 2016 experiences a converse trend where DMU1 is the lease efficient firm with 0.878 score and DUM8 is the most one with 1.209 score. The down trend of DMU1 is since the event of oil rig Haiyang Shi You 981 in Southeast Sea between Vietnam and China in July 2015 cause the dramatically reduce in Chinese visitors. Ben Thanh tourist should diversify their target customers avoid the similar event rather than mostly relying visitors from any one country. Sai Gon Hotel JSC (DMU11) as its MPI score has tendency to reduce and be the least efficiency in period 2016 to 2017 which requests its management board to improve as soon as possible in order not to be kick out of the market.Although the overall trend of hospitality industry is table, DMU1 and DMU8 face with huge fluctuation in efficiency which acquire the management board to review and improve their operation process to ensure the sustainable development of the firm in current competitive market.

According to the result of second time DEA - Malmquist Production Index, the future performance of all DMUs is more consistent efficiency than the past ones. DMU1 seems to have outstanding performance from the past up to future data recorded, however, the declining tendency occurs in the last intervals. It raises the attention to management board of Ben Thanh Tourist and Service JSC to review its performance and operation frequently to ensure their advantages in hospitality industry. DMU9 (OCH) and DMU14 (VNG) are potential to perform better in future. The rest DMUs are stable within score interval from 0.969 to 1.054 .

\section{References}

[1] Min, H., \& Min, H., Benchmarking the quality of hotel services: managerial perspectives, Int. J. Qual. Reliab. Manage. 14 (1997), 582-597. 
[2] Chen, C. T., Hu, J. L., \& Liao, J. J., Tourists' nationalities and the cost efficiency of international tourist hotels in Taiwan, Afr. J. Business Manage. 4 (2010), 3440-3446.

[3] Dyson, R. G., Allen, R., Camanho, A. S., Podinovski, V. V., Sarrico, C. S., \& Shale, E. A., Pitfalls and protocols in DEA, Eur. J. Oper. Res. 132 (2001), 245-259.

[4] Hsieh, L. F., Wang, L. H., Huang, Y. C., \& Chen, A., An efficiency and effectiveness model for international tourist hotels in Taiwan, Service Ind. J. 30 (2010), 2183-2199.

[5] Johns, N., Howcroft, B., \& Drake, L., The use of data envelopment analysis to monitor hotel productivity, Progr. Tourism Hosp. Res. 3 (1997), 119-127.

[6] Hwang, S. N., \& Chang, T. Y., Using data envelopment analysis to measure hotel managerial efficiency change in Taiwan, Tourism Manage. 24 (2003), 357-369.

[7] Chiang, W. E., Tsai, M. H., \& Wang, L. S. M., A DEA evaluation of Taipei hotels, Ann. Tourism Res. 31 (2004), 712-715.

[8] Barros, C. P., Measuring efficiency in the hotel sector, Ann. Tourism Res. 32 (2005), 456-477.

[9] Barros, C. A. P., \& Santos, C. A., The measurement of efficiency in portuguese hotels using data envelopment analysis, J. Hosp. Tourism Res. 30 (2006), 378-400.

[10] Onut S and S Soner, "Energy Efficiency Assessment for the Antalya Region Hotels in Turkey, Energy Buildings, 38 (8) (2006), 964-997.

[11] Chen, C. F., Applying the stochastic frontier approach to measure hotel managerial efficiency in Taiwan, Tourism Manage. 28 (2007), 696-702.

[12] Davutyan, Nurhan, Measuring the quality of hospitality at Antalya, Int. J. Tourism Res. 9 (2007), $51-57$.

[13] Min, H., Min, H., \&Joo, S. J., A data envelopment analysis-based balanced scorecard for measuring the comparative efficiency of Korean luxury hotels, Int. J. Qual. Reliab. Manage. 25 (2008), 349-365.

[14] Barros, C. P., Peypoch, N., \&Solonandrasana, B., Efficiency and productivity growth in hotel industry, Int. J. Tourism Res. 11 (2009), 389-402.

[15] Perrigot, R., Cliquet, G., \& Piot-Lepetit, I., Plural form chain and efficiency: insights from the French hotel chains and the DEA methodology, Eur. Manage. J. 27 (2009), 268-280.

[16] Tourist, M. N.,Statistic figure, Retrieved from Ministry National Administration of Tourist: http://vietnamtourism.gov.vn/index.php/items/13461, (2018, March). 
[17] Yen, F. L., \& Othman, M., Data envelopment analysis to measure efficiency of hotels in Malaysia, SEGi Rev. 4 (2011), 25-36.

[18] Chen, C. T., Hu, J. L., \& Liao, J. J., Tourists' nationalities and the cost efficiency of international tourist hotels in Taiwan, Afr. J. Business Manage. 4 (2010), 3440-3446.

[19] Hsieh, L. F., \& Lin, L. H., A performance evaluation model for international tourist hotels in Taiwan - an application of the relational network DEA, Int. J. Hosp. Manage. 29 (2010), $14-24$.

[20] Hsieh, L. F., Wang, L. H., Huang, Y. C., \& Chen, A., An efficiency and effectiveness model for international tourist hotels in Taiwan, Service Ind. J. 30 (2010), 2183-2199.

[21] Assaf, A., \&Knežević, C. L., The performance of the Slovenian hotel industry: evaluation post-privatisation, Int. J. Tourism Res. 12 (2011), 462-471.

[22] Avkiran, Necmi, Applications of Data Envelopment Analysis in the Service Sector, 2011, 10.1007/978-1-4419-6151-8_15

[23] Wang, F. C., Hung, W. T., \& Shang, J. K., Measuring pure managerial efficiency of international tourist hotels in Taiwan, Service Ind. J. 26 (2006), 59-71.

[24] Yen, F. L., \& Othman, M., Data envelopment analysis to measure efficiency of hotels in Malaysia, SEGi Rev. 4 (2011), 25-36.

[25] Honma, S., \& Hu, J. L., Analyzing Japanese hotel efficiency, Tourism Hosp. Res. 12 (2012), 155-167.

[26] Manasakis, C., Apostolakis, A., \&Datseris, G., Using data envelopment analysis to measure hotel efficiency in Crete, Int. J. Contemp. Hosp. Manage. 25 (2013), 510-535.

[27] Katarina Poldrugovaca, M. T., Efficiency in the hotel industry: an empirical examination of the most influential factors, Economic REsEaRch-Ekonomska istRaživanja, (2016). 